\title{
Effects of organic composition on the anaerobic biodegradability of food
} waste

\author{
Yangyang Li ${ }^{\text {a, b }}$, Yiying Jin a, b,*, Aiduan Borrion ${ }^{\text {c }}$, Hailong Li ${ }^{\text {d }}$, Jinhui Li ${ }^{\text {a, b }}$ \\ a, School of Environment, Tsinghua University, Beijing 100084, China \\ b, Key Laboratory for Solid Waste Management and Environment Safety (Tsinghua University), \\ Ministry of Education of China, Tsinghua University, Beijing 100084, China \\ c, Dept of Civil, Environ \& Geomatic Eng, University College London, LondonWC1E 6BT, UK \\ d, Mälardalen University, School of Business, Society and Engineering, SE-721 23 Västerås, \\ Sweden
}

\section{Abstract}

This work investigated the influence of carbohydrates, proteins and lipids on the anaerobic digestion of food waste (FW) and the relationship between the parameters characterising digestion. Increasing the concentrations of proteins and lipids, and decreasing carbohydrate content in FW, led to high buffering capacity, reduction of proteins (52.7-65.0\%) and lipids (57.4-88.2\%), and methane production (385-627 $\mathrm{mLCH}_{4} / \mathrm{g}$ volatile solid), while achieving a short retention time. There were no significant correlations between the reduction of organics, hydrolysis rate constant $\left(0.25-0.66 \mathrm{~d}^{-1}\right)$ and composition of organics. Principal Component Analysis revealed that lipid, $\mathrm{C}$, and $\mathrm{N}$ contents as well as the $\mathrm{C} / \mathrm{N}$ ratio were the principal components for digestion. In addition, methane yield, the final concentrations of total ammonia nitrogen and free ammonia nitrogen, final $\mathrm{pH}$ values, and the reduction of proteins and lipids could be predicted by a second-order polynomial model, in terms of the protein and lipid weight fraction.

Keywords: Food waste; Anaerobic digestion; Organic composition; Methane; Statistical analysis 


\section{Introduction}

Food waste (FW) is highly biodegradable, and could act as an excellent substrate for anaerobic digestion (AD) (Jin et al., 2015). Using AD for treating FW has attracted much attention due to its benefit, including energy recovery and waste stabilization (Browne and Murphy, 2013; Kafle and Kim, 2013). The organic composition of FW, however, varies significantly according to regions, seasons, collection schemes, and processing characteristics (Galanakis, 2015), thus leading to differences in methane yield ranging between 0.210 and $0.591 \mathrm{~m}^{3} / \mathrm{kg}$ volatile solids (VS) (De Clercq et al., 2016). Biological stability depends on the degradability of organic matter (Tambone et al., 2009; Wagner et al., 2013), therefore, the optimal operating conditions and inhibition effects of different AD process will differ due to the diversity of the organic components in feedstock (Chang and Hsu, 2008; Richard, 1997).

FW consists of three principal organic components: carbohydrates, proteins and lipids, which have different theoretical methane yields and bioconversion rates (Esposito et al., 2012). Carbohydrate-rich feedstock could result in unfavourable carbon/nitrogen $(\mathrm{C} / \mathrm{N})$ ratios in the product due to its limited nutrients and rapid acidification (Paritosh et al., 2017). Volatile fatty acids (VFAs) would accumulate in the digester, which results in a progressive $\mathrm{pH}$ decrease when acidification was faster than the methanogenic process, thus inhibiting methanogenic activity (Siegert and Banks, 2005). Anaerobic treatment of protein-rich feedstock could face risks associated with high concentration of ammonia, which would inhibit methanogenic 
activity (Chen et al., 2008). Lipid-rich feedstock presents higher methane-production potential, compared to carbohydrate-rich and protein-rich feedstocks (Angelidaki and Sanders, 2004). Anaerobic treatment of high-lipid feedstock may lead to a rapid drop in $\mathrm{pH}$, inhibition of long chain fatty acids and sludge flotation, causing problems for operation (Sun et al., 2014). Studies have found that the three organic compositions have synergistic effects on improving process kinetics during co-digestion of paunch, blood and DAF sludge (Astals et al., 2014).

To overcome inhibition caused by high concentrations of ammonia and / or long chain fatty acids, and improve methane production, previous research focused on the impacts of operation parameters on FW digestion performance, such as digestion temperature, organic loading rate, feedstock $\mathrm{C} / \mathrm{N}$ ratio, inoculum characteristics and feed to inoculum ratios (Nie et al., 2013; Schnurer and Jarvis, 2010; U Kun Kiran et al., 2014). Although these factors should be considered when possible, selecting appropriate organic compositions for FW digestion is important. Considering this, the influence of organic composition has often been simplified to optimising the $\mathrm{C} / \mathrm{N}$ ratio (Astals et al., 2014), where the ideal values range between 25 to 30 (Dioha et al., 2013). $\mathrm{C} / \mathrm{N}$ ratios, however, are too general to determine the digestion performance (e.g., methane yield and organic reduction) of different organic compositions. Even for a given FW C/N ratio, the carbohydrate, protein and lipid compositions, and methane production potentials, can differ greatly.

In contrast, to evaluate the influence of different compositions on FW biodegradability, some studies have extended their interest in anaerobic co-digestion 
of FW to different feedstocks, including sewage sludge (Dai et al., 2013; Edwards et al., 2017; Kim et al., 2004), cattle and dairy manure (El-Mashad and Zhang, 2010; Li et al., 2010; Zhang et al., 2013), fruit and vegetable waste (Lin et al., 2011), piggery wastewater (Zhang et al., 2011), yard waste (Brown and Li, 2013), straw (Yong et al., 2015) and other municipal and agro-industrial wastes (Alibardi and Cossu, 2016; Wu et al., 2016). The characteristics of compositions of the three organics in the above feedstocks differed from those in FW, such as lipids. Currently, for the mono-digestion of FW, there is limited information about how its organic compositions affect its digestion performance and correlations with digestion performance and process kinetics parameters. Therefore, studying the performance of mono-digestion systems and assessing the relationships between those parameters and the main organic compositions are essential to forecast and improve the performance of AD systems.

This paper aims to evaluate how and to what extent varying organic compositions affect the anaerobic degradability of FW and identify interactions between the three organic compositions and digestion performance parameters, focusing on methane production, the hydrolysis rate constant, reduction efficiency of organics and operation parameters in AD by investigating the effects of 12 different organic compositions. To predict and optimize the operating parameters of AD systems, modified second-order polynomial models were developed to identify key process parameters for FW digestion.

\section{Materials and Methods}




\subsection{FW preparation}

Twelve types of FW were collected from different school canteens and analysedin this study. First, impurities (such as large bones, plastics and metals) were manually removed. The samples were then macerated into particles by a macerator to an average size of $1-2 \mathrm{~mm}$. The samples were stored at $4{ }^{\circ} \mathrm{C}$ in a refrigerator for the subsequent experiments. The variation of FW compositions were obtained based on a literature review and measurements of samples from five typical Chinese cities (e.g., Beijing in North China; Jiaxing in Zhejiang province, East China; Xining in Qinghai province, Northwest China; Qingdao in Shandong province, coastal East China and Guiyang in Guizhou province, South China). The compositions and their characteristics are listed in Table 1.

\subsection{Batch digestion experiment}

\subsubsection{Batch AD tests}

The biochemical methane potential (BMP) assay has been proven to be a relatively simple and reliable method for obtaining the rate and extent of converting organic matter to methane. Batch tests were conducted in 15 parallel $500 \mathrm{~mL}$ glass bottles at $37^{\circ} \mathrm{C}$ with an automatic methane potential test system II, supplied by Bioprocess Control (Lund, Sweden). It features automatic sample stirring, an acid gas (such as $\mathrm{CO}_{2}$ or $\mathrm{H}_{2} \mathrm{~S}$ ) removal system and a biomethane yield recording system. The system conducts fast and accurate on-line measurements of ultra-low biogas and biomethane flow to determine biogas potential. All the reactors were started at the same time, and agitation was synchronous, following the same speed and intervals. The evaluation of 
biodegradability and decomposition rate of organic material was, therefore, more accurate than other batch assays.

\subsubsection{Inoculum}

Seed sludge was obtained as an inoculum from a steady-operation digester $\left(37^{\circ} \mathrm{C}\right)$ in a FW treatment plant. After a two-day gravity sedimentation period, large particles or grit were removed from the inoculum using a $2 \mathrm{~mm}$ sieve, and the total solid (TS) and VS contents were $12.38 \%$ and $8.26 \%$, respectively, while $\mathrm{pH}$ was 7.79 before it was mixed with the FW.

\subsubsection{AD experimental setup}

The total sample amount in each reactor was $400 \mathrm{~g}$, and the feed to inoculum ratio was 0.5 on a VS basis. The upper area of each reactor was flushed with nitrogen for at least 1 min to ensure anaerobic conditions and the reactor was quickly sealed afterwards. All the reactors were put into a water bath so the digestion system could be maintained at a mesophilic temperature $\left(37^{\circ} \mathrm{C}\right)$ for $\mathrm{AD}$. For each test, three samples were created and two digesters, containing only inoculum were incubated to correct for biogas yield from inoculum.

\subsection{Kinetic study}

The hydrolysis constant and ultimate methane yield obtained from each test were calculated according to an approach reported by Koch and Drewes (Koch and Drewes, 2014; Koch et al., 2015), which favours Monod-type kinetics. Cumulative methane production $B$ is described by the following equation: 
$B=\frac{F_{0} \cdot G \times k_{h} \times t}{1+k_{h} \times t}$

where $F_{0}$ is the influent concentration of degradable particulate $\operatorname{COD}(\mathrm{g} / \mathrm{L})$ and $G$ is the transformation factor $\left(0.35 \mathrm{~L} \mathrm{CH}_{4} / \mathrm{g} \mathrm{COD}\right)$. In contrast to balancing a continuous stirred-tank reactor, where $F_{0}$ is concentration $(\mathrm{g} \mathrm{COD} / \mathrm{L}), F_{0}$ in a batch test is mass $(\mathrm{g}$ COD). Thus, $F_{0} \cdot G$ can be interpreted as the ultimate methane yield of the added substrate $\left(\mathrm{mL} \mathrm{CH}_{4} / \mathrm{gVS}\right), k_{h}$ is the hydrolysis rate constant $\left(\mathrm{d}^{-1}\right)$ and $t$ is the duration of the batch test (d). The two constants, $k_{h}$ and $F_{0} \cdot G$, can be derived from the slopes and intercepts of the experimental data plotted using the linearised version of Eq. (1).

\subsection{Analytical methods}

pH was measured using a pH meter (FE20, Mettler,Switzerland). TS and VS were determined according to the standard methods of the American Public Health Association (Clesceri and American, 1996). The concentrations of protein and lipid were determined following the Kjeldahl method and by using a Soxhlet device, respectively (Naumann et al., 1997). Concentrations of total ammonia nitrogen (TAN) and free ammonia nitrogen (FAN) were determined as previously reported (Siles et al., 2010).

\subsection{Statistical analysis}

\subsubsection{ANOVA analysis}

Statistically significant differences in the results were identified (changes in organic reduction and process parameters) by ANOVA analysis ( $p<0.05)$, performed by $\mathrm{R}$ software 3.3.2. 


\subsubsection{Pearson correlation analysis}

Pearson correlation analysis $(p<0.05)$ was also conducted to discuss significant relationships between the above parameters, using IBM SPSS Statistics 20 .

\subsubsection{Principal component analysis}

Principal component analysis was conducted on data that were formed by 3 types $x$ 10 variables (TS, VS, carbohydrate, protein, lipid, $\mathrm{C}, \mathrm{H}, \mathrm{N}, \mathrm{C} / \mathrm{N}$ and BMP). Leave-one-out cross validation was used, and the analysis was performed using IBM SPSS Statistics 20.

\subsubsection{Second-order polynomial model analysis}

Response surface methodology was used to optimize the studied parameters. The functional relationships between responses $(M)$ and the set of factors ( $X$ and $Y$ ) were described by estimating the coefficients of the following second-order polynomial model, based on experimental data.

$M=M_{0}+a X+b Y+c X^{2}+d Y^{2}+f X Y$

where $M_{0}$ is a constant, $a$ and $b$ are linear coefficients, $c$ and $d$ are quadratic coefficients, and $f$ is the interaction coefficient.

\section{Table 1.}

\section{Results and Discussion}

3.1. Methane production and hydrolysis constant

\subsubsection{Characterization of the feedstock}

Of the physical and chemical characteristics of the 12 types of FW used in this study, there were smaller variations of $\mathrm{H}$ and $\mathrm{N}$ content, while lipid and carbohydrate 
contents exhibited larger variation (Fig. 1). The VS/TS ratios ranged from 95\% to 97\%, and organic components varied widely. Carbohydrates varied from $3.1 \%$ to $12.0 \%$, in comparison to $3.4-7.9 \%$ and $1.0-10.2 \%$ for proteins and lipids, respectively (wet basis). The BMP of feedstock ranged from 435 to $687 \mathrm{~mL} / \mathrm{g} \mathrm{VS}$ (Table 2), which was statistically correlated with the lipid $(p<0.01)$ and carbohydrate $(p<0.05)$ contents, while it had no significant differences from protein concentration (Table 3)

\section{Fig. 1.}

Table 2.

\section{Table 3.}

\subsubsection{Methane yield}

Different sample compositions with varying biodegradation rates had varying methane production rates and yields.

(1) Cumulative methane yield

Different organic compositions of FW produced different cumulative methane yields, ranging from 385 to $627 \mathrm{~mL} \mathrm{CH}_{4} / \mathrm{g}$ VS (Fig. 2a). Lipids had the highest BMP, while carbohydrates had the lowest (Angelidaki and Sanders, 2004), therefore those with higher lipid content would produce higher methane yield than those with higher carbohydrate content. The highest methane yield was obtained from sample 11, which had a carbohydrate-protein-lipid ratio of 0.8: 0.5: 1, followed by sample $12(574 \mathrm{~mL}$ $\mathrm{CH}_{4} / \mathrm{g}$ VS) and sample 8 (565 $\mathrm{mL} \mathrm{CH}_{4} / \mathrm{g}$ VS), which had carbohydrate-protein-lipid ratios of $0.4: 1.1: 1$ and 1.2: $0.8: 1$, respectively. 


\section{Fig. 2.}

(2) Specific methane yield rate

There were remarkable differences between the peak patterns of the specific methane production rate curves for 12 samples (Fig. 2b).

In the sample with a carbohydrate-protein-lipid ratio of 12.2: 3.4: 1, carbohydrate accounted for $73 \%$, indicating relatively intense methane production. Peak values were achieved within the first $11 \mathrm{~h}$ (Table 4), and up to $98 \%$ of the total methane yield was produced within the duration of the first peak (during the first $22 \mathrm{~h}$ ).

Two main peaks were obtained from the other 11 samples. The first peaks indicated shorter durations, but higher peak values than the second peaks (Table 4). The first peaks appeared during the first 11-22 h, while the second peaks appeared between $177-395 \mathrm{~h}$. The values of first peaks ranged from 12.7 to $63.7 \mathrm{~mL} \mathrm{CH}_{4} /(\mathrm{g} \mathrm{VS} \mathrm{h})$, and the values of the second peaks ranged from 3.4 to $8.7 \mathrm{~mL} \mathrm{CH}_{4} /(\mathrm{g} \mathrm{VS} \mathrm{h})$, which is 42.8-90.7\% lower than the first. For all samples, methane production commenced immediately after $\mathrm{AD}$ process commenced and methane was mainly produced during the second stage, which accounted for $55-74 \%$ of the total methane yield.

The occurrence of these peaks was due to the degradation of easily-degradable organics and macromolecular insoluble materials (such as proteins and lipids). The reason for different peak patterns could be due to different organic compositions, particularly carbohydrate-protein-lipid ratios, which play different roles in the bioconversion rates of organics and biomethane production. FW was characterised by a high degree of easily-degradable material, and the first intense peak could be from 
the soluble organic matter with small molecules, which could be easily and rapidly degraded. Variations in the numbers of peaks and their values could be due to differences in the mixing ratios of carbohydrates, proteins and lipids in samples. This phenomenon consistent with the results of other $\mathrm{AD}$ research on livestock manure ( $\mathrm{Li}$ et al., 2015), pig manure co-digested with dewatered sewage sludge (Zhang et al., 2014), and FW co-digested with municipal wastewater (Koch et al., 2015).

Additionally, from the Person correlation analysis, the time taken for $90 \%$ of methane production ( $\mathrm{t}_{90}$ ) was $15 \mathrm{~h}$ for $\mathrm{FW}$ with a carbohydrate-protein-lipid ratio of 12.2:3.4:1 (sample 1), compared to a range of 196 - $409 \mathrm{~h}$ for the others (Table 4). Longer $t_{90}$ values were obtained from FW with lower carbohydrate $(p<0.05)$ and higher lipid content $(p<0.01)$. FW with higher protein and lipid but lower carbohydrate content produced lower values for the first peaks $(p<0.05)$, while the values of the second peaks exhibited a negative relationship with carbohydrate $(p<$ 0.05). These results could be due to the high hydrolysis rate of carbohydrate during the AD process, compared to lipids and proteins. It could be concluded that the hydrolysis rate of complex material limits its overall biomethane production rate when refractory organic compounds, such as lipids and proteins are the main substrates for an anaerobic digester. This situation could be different when soluble hydrolysed organic materials are fed into the digester, such as starch, the main form of carbohydrate in FW, and the methanogenic phase could be the rate-limiting step.

\section{Table 4.}

\subsubsection{Hydrolysis constant}


The results of the kinetic model for the hydrolysis constant $\left(k_{\mathrm{h}}\right)$ and ultimate methane yield $\left(F_{0} G\right)$ are presented in Fig. 3. Statistical indicators $\left(R^{2}\right)$ were calculated following the approach of Koch and Drewe, and are in the range of 0.8341-0.9905, indicating that the approach fits the 12 types of FW subjected to the AD process.

As described previously (Koch et al., 2015), $k_{\mathrm{h}}$ represents the reciprocal of the time when $50 \%$ of $F_{0} G$ was obtained. Therefore, high $k_{\mathrm{h}}$ values mean rapid degradation of organics and biomethane production. Both $k_{\mathrm{h}}$ and $F_{0} G$ varied with the carbohydrate, protein and lipid proportions. The FW with a carbohydrate-protein-lipid ratio of 3.3:1.6:1 (sample 3) achieved the highest $k_{\mathrm{h}}$ value $\left(0.66 \mathrm{~d}^{-1}\right)$, followed by $0.43-0.55$ $\mathrm{d}^{-1}$ for those with carbohydrate-protein-lipid ratios of (12.7-15.5):(0.7-0.9):1 (sample 7-9), while sample 1 (12.2: $3.4: 1)$, which had the highest carbohydrate content (12.0\%, wet basis), produced the lowest $k_{\mathrm{h}}\left(0.25 \mathrm{~d}^{-1}\right)$ (Fig. 3). Good, simulated $F_{0} G$ results were obtained for samples $1-3$ and $8-12$. Higher $F_{0} G$ values were achieved for samples with carbohydrate-protein-lipid ratios of (1.7-2.2): (0.7-0.9): 1 . There was no positive relationship between $k_{\mathrm{h}}$ and the levels of the three organic components.

The main causes of the differences between $k_{\mathrm{h}}$ and $F_{0} G$ values can be explained as follows: 1) the specific types of anaerobic biodegradation enzyme are responsible degrading specific types of organics, for example, a particular protease contributes to the decomposition of the corresponding protein to amino acids during $\mathrm{AD}$ of $\mathrm{FW}$. Variations of organics (carbohydrate, protein, and lipid) resulted in differences in 
degradation characteristics; 2) the degradation efficiency of the same types of organics was affected by the surface area to volume ratio of particles during the digestion process, hence, the degradation rate of the same types of compounds, such as proteins, can differ. Additionally, during the AD process, mutual influences from the three organics could contribute to these differences. For example, glucose, which is the main hydrolysate of carbohydrate, could inhibit protease formation, which is responsible for decomposing proteins (Breure et al., 1986).

\section{Fig. 3.}

\subsection{Organics degradation after $\mathrm{AD}$}

\subsubsection{Organics reduction}

For TS, 53.5-60.8\% of it could be removed, while a reduction range of $66.6-70.1 \%$ was achieved for VS (Fig. 4). The reduction efficiency of protein varied from 52.7\% to $65.0 \%$, in comparison with $57.4-88.2 \%$ for lipids.

Protein degradation increased with decreasing carbohydrate levels $(p<0.01)$, while proteins $(p<0.01)$ and lipids $(p<0.05)$ increased. This means that protein degradation could be reduced with increasing concentrations of carbohydrates in the feedstock. It has been reported that glucose could cause the repression of protease formation during $\mathrm{AD}$ processes (Breure et al., 1986), which is responsible for decomposing proteins to amino acids. Carbohydrate flux through the catabolic system of the bacteria is higher with high carbohydrate contents in the feedstock, which could be a regulating factor for the activity of the protein degradation system, e.g. by (catabolite-) repression of proteolytic enzyme synthesis (Atkinson, 1968). Therefore, 
as two major organic components in FW, a two-phase digestion system could relieve repression caused by protein degradation.

No significant difference could be found for final TS and VS reduction. Additionally, lipid degradation was significantly and positively correlated with lipid levels $(p<0.01)$, while no significant correlations with carbohydrate and protein were found. Studies on AD for high-strength lipid wastes have reported numerous negative impacts from lipid inhibition during the AD process, including inhibition by long chain fatty acids, inhibition of acetolactic and methanogenic bacteria, transport limitations between soluble organic matter and microbial cells, sludge flotation, digester foaming and other operational challenges (Cirne et al., 2007; Sun et al., 2014).

\section{Fig. 4.}

\subsubsection{Relationship between $p H$, TAN, FAN of the system and methane yield}

After digestion for $30 \mathrm{~d}$ at $37^{\circ} \mathrm{C}$, the $\mathrm{pH}$ values of all the digesters stabilised at a level between 7.79-7.99, indicating steady operational conditions (Fig. 5). All TAN and FAN concentrations after AD ranged from 1654-2441 mg/L and 126-266 mg/L, respectively. The inhibition concentration range of TAN is $1500-7000 \mathrm{mg} / \mathrm{L}$ (Hejnfelt and Angelidaki, 2009; Rajagopal et al., 2013; Yenigün and Demirel, 2013), and for FAN it is 435-757 mg/L (González-Fernández and García-Encina, 2009), so inhibition of TAN and FAN did not occur during the entire period of digestion.

\section{Fig. 5.}

Higher $\mathrm{pH}$ values were observed for FW with higher protein and lipid content, and 
lower carbohydrate content. TAN was negatively correlated with carbohydrate content $(p<0.01)$ and positively correlated with protein content $(p<0.01)$, while the $\mathrm{C} / \mathrm{N}$ ratio was positively correlated with carbohydrate content and negatively correlated with protein content. Increasing the protein and lipid content in FW resulted in high $\mathrm{pH}$ and FAN values, while increasing carbohydrate content resulted in low $\mathrm{pH}$ and FAN values. This suggests that increasing the proportion of protein in feedstock could be beneficial for maintaining high alkalinity and a stable $\mathrm{pH}$ during the $\mathrm{AD}$ process, because proteins are nitrogen-containing compounds that contribute to TAN and FAN in the digestion system. High carbohydrate content did not achieve a sufficient alkalinity for preventing $\mathrm{pH}$ fluctuations in an anaerobic digester.

FAN concentration mainly depends on TAN concentration, digestion temperature and $\mathrm{pH}(\varnothing$ stergaard, 1985). Thus, there is a positive correlation $(p<0.01)$ between TAN, $\mathrm{pH}$ and FAN. The degradation and conversion of protein to ammonia and ammonia-nitrogen increased FAN and TAN concentrations, thus increasing $\mathrm{pH}$ in the bioreactor during the $\mathrm{AD}$ process. $\mathrm{FW}$ with greater protein reduction generated higher final $\mathrm{pH}, \mathrm{FAN}$ and TAN values.

\subsection{Correlation among AD parameters}

\subsubsection{Relationships among digestion performance parameters}

The processing parameters of FW during AD varied widely between the different organic compositions. The correlation matrix reveals some significant relationships between digestion performance parameters.

Methane production was strongly, positively correlated with lipid reduction ( $p<$ 
$0.01), \mathrm{pH}(p<0.05)$, FAN $(p<0.05)$ and protein reduction $(p<0.05)$. This could be due to the high biochemical methane potential from lipids and proteins, while the high alkalinity guaranteed the methane production. This does not mean, however, that continuously increasing FAN could promote methane yield, because ammonia and ammonium accumulated during protein breakdown are the primary inhibitors to the AD process (Yenigün and Demirel, 2013).

VS/TS ranged from $95 \%$ to $98 \%$, and the reduction of VS after AD of FW also contributed to TS reduction, so a positive correlation was found between them $(p<$ 0.01). Additionally, although carbohydrates, proteins, and lipids contribute to organics in FW, no significant correlation was observed between them. This could be due to the collaborative effect of reduction by these three organic compounds and their total reduction expressed in terms of TS and VS.

Extending the retention time for digestion promoted the complete conversion of degradable organics to methane when successful reactor operation was achieved. t90 $_{90}$ was significantly and positively correlated with methane production $(p<0.01), \mathrm{pH}(p$ $<0.05)$, FAN concentration $(p<0.05)$ and lipid reduction $(p<0.01)$. The reduction of

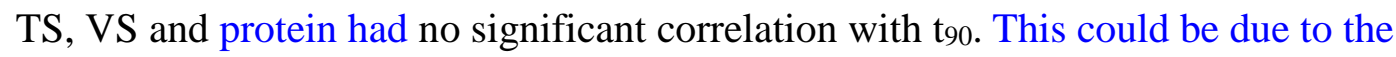
following reasons. Firstly, the conversion process of protein to biogas is steady during the whole digestion process, while cumulative biogas production increased linearly with protein removal efficiency (Yang et al., 2015). Secondly, inhibition during AD of FW could be due to the presence of long chain fatty acids that are associated with the high lipid content, which resulted in the highest BMP compared to carbohydrate and 
protein. Thirdly, as analysed above, reduction of TS and VS could have a collaborative effect on methane production. These three reasons may also be why the hydrolysis rate constant $k_{h}$ had no significant relationship with the above parameters.

For the specific methane production rate, higher values of the first peaks resulted in a negative correlation with methane yield $(p<0.05), \mathrm{pH}(p<0.05)$, protein reduction $(p<0.05)$, lipid reduction $(p<0.05)$ and $190(p<0.01)$. The values of the second peaks had a positive relationship with TAN $(p<0.05)$, protein reduction $(p<0.05)$, and $190(p<0.01)$. The first peaks were of higher values and appeared earlier than the second, resulting in a negative correlation between the first and second peaks $(p<$ $0.01)$.

The $\mathrm{C} / \mathrm{N}$ ratios were negatively correlated with TAN $(p<0.05)$, protein reduction $(p<0.01)$ and the values of the second methane yield peak $(p<0.05)$, but no significant relationship with methane production was found. Low $\mathrm{C} / \mathrm{N}$ could cause higher ammonia-nitrogen release and higher volatile fatty acid accumulation. In this study, the $\mathrm{C} / \mathrm{N}$ ratio in $\mathrm{FW}$ ranged from 10 to 18 , so it could be concluded that the $\mathrm{C} / \mathrm{N}$ ratio of $\mathrm{FW}$ does not affect methane yield. Besides, a high $\mathrm{C} / \mathrm{N}$ ratio indicates low protein content in the feedstock, which would not be conducive to the formation of protein-hydrolyzed TAN.

\subsubsection{Results of second-order polynomial models}

An implication of these variations is that the differing compositions of the initial samples for AD affected biodegradability and, therefore, methane production rates, methane yields and organics reduction. A second-order polynomial model was used to 
predict parameters that characterised the FW composting process in terms of the weight fractions of proteins and lipids; the coefficients are listed in Table 5. Higher $R^{2}$ values were obtained from the regressions models for parameters such as ultimate methane yield, final TAN and FAN concentrations, final $\mathrm{pH}$ values and reduction of proteins and lipids, which were between $0.727-0.988$, indicating consistency with the experimental data. The values of the first peaks from the model were not consistent, achieving a $R^{2}$ value of 0.572. Chang and Hsu (2008) (Chang and Hsu, 2008) used a second-order polynomial model to determine important parameters that characterised the FW composting process in terms of protein and lipide weight fractions, and found that the experimental and predicted results were consistent.

Two other FW samples were tested in the same digestion system. As shown in Table 5, the predicted results of the parameters with higher coefficients of determination, based on the models, were consistent with experimental results.

\section{Table 5.}

\subsubsection{Feasibility of practical project application}

When applied to new substrates, such as FW with high moisture and fat content, existing designs typically perform poorly or fail, so regularly monitoring key process parameters and making necessary operational adjustments on time would be essential to prevent digester failure. The principal component analysis results for all the FW samples indicate that two significant components were extracted, explaining $98.9 \%$ of the variance in the matrix. The main component, i.e. the first principal component, explained $67.5 \%$ of the variance, while the second principal component explained 
$31.4 \%$ of the variance. The principal variables of the first principal component were the lipid, $\mathrm{C}$ and $\mathrm{N}$ content, while $\mathrm{C} / \mathrm{N}$ ratio was the second principal component.

According to the analysis of the relationship between different AD parameters, the methane yield, treatment durations and organics reduction were significantly affected by the carbohydrate-protein-lipid ratios. These findings suggest that an inappropriate mixing ratio range of these three compounds can inhibit methane production and organics degradation during the AD of FW. In this study, appropriate carbohydrate, protein and lipid percentages in FW could be within ranges of 9.2-11.0\%, 3.6-4.6\% and $2.9-5.3 \%$, respectively (wet basis). To forecast how variations in composition affect the $\mathrm{AD}$ process during engineering design and process optimization, a possible strategy for predicting the $\mathrm{AD}$ characteristics of FW could be to analyse the initial compositions of FW, such as $\mathrm{C}, \mathrm{N}$ and lipid content, and then adjust the carbohydrate-protein-lipid ratios, for example, increasing the lipid content if it is less than $5.5 \%$, or decreasing it by mixing FW with organics of lower lipid content to achieve improved degradation efficiency.

Monitoring the performance indicators would also be required, especially sensitive parameters such as VFA concentrations, methane yields and $\mathrm{pH}$, and adjust the relative operation parameters in a timely manner during the AD process. In addition, predicting parameters related to the operating parameters by a second-order polynomial model could aid in taking precautionary measures to prevent unsteady operational problems during digestion.

\section{Conclusions}


Carbohydrate, protein and lipid contents correlated with performance parameters, thus affecting methane yield (385 to $627 \mathrm{~mL} / \mathrm{gVS}$ ) and final protein $(52.7-65.0 \%)$ and lipid reduction (57.4-88.2\%). The hydrolysis rate constant $\left(0.25-0.66 \mathrm{~d}^{-1}\right)$ had no significant correlations with the compositions of the three organics. Lipid, C, and N content and the $\mathrm{C} / \mathrm{N}$ ratio were the first principal components of $\mathrm{FW}$ digestion. Additionally, appropriate carbohydrate, protein and lipid percentages in FW was within ranges of $9.2-11.0 \%, 3.6-4.6 \%$ and $2.9-5.3 \%$, respectively (wet basis). Second-order polynomial models could be used for quick estimation of the digestion parameters.

E-supplementary data for this work can be found in e-version of this paper online (Table S1-S3).

\section{Acknowledgements}

This work was supported by the China scholarship council (CSC No. 201606210435), Jiaxing Lvneng Environmental Technology Co., Ltd. and Beijing TP Environmental Technology Co., Ltd.

\section{References}

1. Alibardi, L., Cossu, R., 2016. Effects of carbohydrate, protein and lipid content of organic waste on hydrogen production and fermentation products. Waste Management, 47, Part A, 69-77.

2. Angelidaki, I., Sanders, W., 2004. Assessment of the anaerobic biodegradability of macropollutants. Re/Views in Environmental Science \& Bio/Technology, 3, 117-129.

3. Astals, S., Batstone, D.J., Mata-Alvarez, J., Jensen, P.D., 2014. Identification of synergistic impacts during anaerobic co-digestion of organic wastes. Bioresource Technology, 169, 421-427.

4. Atkinson, D.E., 1968. The energy charge of the adenylate pool as a regulatory parameter. Interaction with feedback modifiers. Biochemistry, 7. 
5. Breure, A.M., Mooijman, K.A., Andel, J.V., 1986. Protein degradation in anaerobic digestion: influence of volatile fatty acids and carbohydrates on hydrolysis and acidogenic fermentation of gelatin. Applied Microbiology and Biotechnology, 24, 426-431.

6. Brown, D., Li, Y., 2013. Solid state anaerobic co-digestion of yard waste and food waste for biogas production. Bioresource Technology, 127, 275-280.

7. Browne, J.D., Murphy, J.D., 2013. Assessment of the resource associated with biomethane from food waste. Applied Energy, 104, 170-177.

8. Chang, J.I., Hsu, T., 2008. Effects of compositions on food waste composting. Bioresource Technology, 99, 8068-8074.

9. Chen, Y., Cheng, J.J., Creamer, K.S., 2008. Inhibition of anaerobic digestion process: A review. Bioresource Technology, 99, 4044-4064.

10. Cirne, D.G., Paloumet, X., Bj Rnsson, L., Alves, M.M., Mattiasson, B., 2007. Anaerobic digestion of lipid-rich waste-Effects of lipid concentration. Renewable Energy, 32, 965-975.

11. Clesceri, L.S., American, P.H.A., 1996. Standard methods for the examination of water and wastewater, supplement. American Public Health Association Washington, DC.

12. Dai, X., Duan, N., Dong, B., Dai, L., 2013. High-solids anaerobic co-digestion of sewage sludge and food waste in comparison with mono digestions: Stability and performance. Waste Management, 33, 308-316.

13. De Clercq, D., Wen, Z., Fan, F., Caicedo, L., 2016. Biomethane production potential from restaurant food waste in megacities and project level-bottlenecks: A case study in Beijing. Renewable and Sustainable Energy Reviews, 59, 1676-1685.

14. Dioha, I.J., Ikeme, C.H., Nafi U, T., Soba, N.I., Yusuf, M., 2013. Effect of carbon to nitrogen ratio on biogas production. International Research Journal of Natural Sciences, 1, 1-10.

15. Edwards, J., Othman, M., Crossin, E., Burn, S., 2017. Anaerobic co-digestion of municipal food waste and sewage sludge: A comparative life cycle assessment in the context of a waste service provision. Bioresource Technology, 223, 237-249.

16. El-Mashad, H.M., Zhang, R., 2010. Biogas production from co-digestion of dairy manure and food waste. Bioresource Technology, 101, 4021-4028.

17. Esposito, G., Frunzo, L., Giordano, A., Liotta, F., Panico, A., Pirozzi, F., 2012. Anaerobic co-digestion of organic wastes. Reviews in Environmental Science and Bio/Technology, 11, 325-341.

18. Galanakis, C.M., 2015. Food Waste Recovery: Processing Technologies and Industrial Techniques. Academic Press.

19. González-Fernández, C., García-Encina, P.A., 2009. Impact of substrate to inoculum ratio in anaerobic digestion of swine slurry. Biomass and Bioenergy, 33, 1065-1069.

20. Hejnfelt, A., Angelidaki, I., 2009. Anaerobic digestion of slaughterhouse by-products. Biomass and Bioenergy, 33, 1046-1054.

21. Jin, Y., Chen, T., Chen, X., Yu, Z., 2015. Life-cycle assessment of energy consumption and environmental impact of an integrated food waste-based biogas plant. Applied Energy, 151, 227-236.

22. Kafle, G.K., Kim, S.H., 2013. Anaerobic treatment of apple waste with swine manure for biogas production: Batch and continuous operation. Applied Energy, 103, 61-72.

23. Kim, S., Han, S., Shin, H., 2004. Feasibility of biohydrogen production by anaerobic co-digestion of food waste and sewage sludge. International Journal of Hydrogen Energy, 29, 1607-1616.

24. Koch, K., Drewes, J.R.E., 2014. Alternative approach to estimate the hydrolysis rate constant of particulate material from batch data. Applied Energy, 120, 11-15. 
25. Koch, K., Helmreich, B., Drewes, J.R.E., 2015. Co-digestion of food waste in municipal wastewater treatment plants: Effect of different mixtures on methane yield and hydrolysis rate constant. Applied Energy, 137, 250-255.

26. Li, K., Liu, R., Sun, C., 2015. Comparison of anaerobic digestion characteristics and kinetics of four livestock manures with different substrate concentrations. Bioresource Technology, 198, 133-140. 27. Li, R., Chen, S., Li, X., 2010. Biogas production from anaerobic co-digestion of food waste with dairy manure in a two-phase digestion system. Applied Biochemistry and Biotechnology, 160, 643-654.

28. Lin, J., Zuo, J., Gan, L., Li, P., Liu, F., Wang, K., Chen, L., Gan, H., 2011. Effects of mixture ratio on anaerobic co-digestion with fruit and vegetable waste and food waste of China. JOURNAL OF ENVIRONMENTAL SCIENCES, 23, 1403-1408.

29. Naumann, C., Bassler, R., Seibold, R., Barth, C., 1997. Methodenbuch: Die chemische Untersuchung von Futtermitteln. VdLUFA-Verlag.

30. Nie, Y., Jin, Y., Liu, F., 2013. Handbook on solid waste management and technology. Chemical Industry Press.

31. Østergaard, N., 1985. Biogasproduktion i det thermofile temperaturinterval. STUB rapport, 21.

32. Paritosh, K., Kushwaha, S.K., Yadav, M., Pareek, N., Chawade, A., Vivekanand, V., 2017. Food Waste to Energy: An Overview of Sustainable Approaches for Food Waste Management and Nutrient Recycling. Biomed Research International, 2017.

33. Rajagopal, R., Massé, D.I., Singh, G., 2013. A critical review on inhibition of anaerobic digestion process by excess ammonia. Bioresource Technology, 143, 632-641.

34. Richard, T.L., 1997. The kinetics of solid state aerobic biodegradation. Cornell University, Ithica, NY, USA.

35. Schnurer, A., Jarvis, A., 2010. Microbiological handbook for biogas plants. Swedish Waste Management $U, 2009,1-74$.

36. Siegert, I., Banks, C., 2005. The effect of volatile fatty acid additions on the anaerobic digestion of cellulose and glucose in batch reactors. Process Biochemistry, 40, 3412-3418.

37. Siles, J.A., Brekelmans, J., Martin, M.A., Chica, A.F., Martin, A., 2010. Impact of ammonia and sulphate concentration on thermophilic anaerobic digestion. Bioresource Technology, 101, 9040-9048.

38. Sun, Y., Wang, D., Yan, J., Qiao, W., Wang, W., Zhu, T., 2014. Effects of lipid concentration on anaerobic co-digestion of municipal biomass wastes. Waste Management, 34, 1025-1034.

39. Tambone, F., Genevini, P., D Imporzano, G., Adani, F., 2009. Assessing amendment properties of digestate by studying the organic matter composition and the degree of biological stability during the anaerobic digestion of the organic fraction of MSW. Bioresource Technology, 100, 3140-3142.

40. U Kun Kiran, E., Trzcinski, A.P., Ng, W.J., Liu, Y., 2014. Bioconversion of food waste to energy: A review. Fuel, 134, 389-399.

41. Wagner, A.O., Lins, P., Malin, C., Reitschuler, C., Illmer, P., 2013. Impact of protein-, lipid-and cellulose-containing complex substrates on biogas production and microbial communities in batch experiments. Science of the Total Environment, 458, 256-266.

42. Wu, L., Kobayashi, T., Kuramochi, H., Li, Y., Xu, K., 2016. Improved biogas production from food waste by co-digestion with de-oiled grease trap waste. Bioresource Technology, 201, 237-244.

43. Yang, G., Zhang, P., Zhang, G., Wang, Y., Yang, A., 2015. Degradation properties of protein and carbohydrate during sludge anaerobic digestion. Bioresource Technology, 192, 126-130.

44. Yenigün, O., Demirel, B., 2013. Ammonia inhibition in anaerobic digestion: A review. Process Biochemistry, 48, 901-911. 
45. Yong, Z., Dong, Y., Zhang, X., Tan, T., 2015. Anaerobic co-digestion of food waste and straw for biogas production. Renewable Energy, 78, 527-530.

46. Zhang, C., Xiao, G., Peng, L., Su, H., Tan, T., 2013. The anaerobic co-digestion of food waste and cattle manure. Bioresource Technology, 129, 170-176.

47. Zhang, L., Lee, Y., Jahng, D., 2011. Anaerobic co-digestion of food waste and piggery wastewater: focusing on the role of trace elements. Bioresource Technology, 102, 5048-5059.

48. Zhang, W., Wei, Q., Wu, S., Qi, D., Li, W., Zuo, Z., Dong, R., 2014. Batch anaerobic co-digestion of pig manure with dewatered sewage sludge under mesophilic conditions. Applied Energy, 128, $175-183$. 
Table 1. Characteristics of the $12 \mathrm{FW}$ compositions for AD runs (No. 1-No. 12).

\begin{tabular}{|c|c|c|c|c|c|c|c|c|c|c|c|c|}
\hline Parameters & No. 1 & No. 2 & No. 3 & No. 4 & No. 5 & No. 6 & No. 7 & No. 8 & No. 9 & No. 10 & No. 11 & No. 12 \\
\hline TS $(\%)$ & 16.7 & 19.1 & 17.2 & 20.5 & 19.7 & 19.6 & 20.0 & 20.8 & 19.2 & 20.9 & 24.7 & 18.7 \\
\hline $\operatorname{VS}(\%)$ & 16.4 & 18.5 & 16.7 & 19.7 & 19.0 & 18.9 & 19.3 & 19.9 & 18.4 & 20.0 & 23.5 & 17.9 \\
\hline Carbohydrate (\%) & 12.0 & 10.8 & 9.4 & 11.0 & 10.1 & 9.3 & 9.2 & 8.3 & 7.6 & 7.7 & 8.1 & 3.1 \\
\hline Protein $(\%)$ & 3.4 & 4.0 & 4.5 & 3.6 & 4.3 & 4.6 & 4.6 & 5.0 & 5.2 & 5.3 & 5.3 & 7.9 \\
\hline Lipid (\%) & 1.0 & 3.7 & 2.9 & 5.3 & 4.7 & 5.0 & 5.5 & 6.6 & 5.6 & 7.1 & 10.2 & 6.9 \\
\hline $\mathrm{C}(\% \mathrm{TS})$ & 43.0 & 45.5 & 45.6 & 46.9 & 46.5 & 47.1 & 47.5 & 48.8 & 48.4 & 49.4 & 51.5 & 51.5 \\
\hline $\mathrm{H}(\% \mathrm{TS})$ & 6.5 & 6.8 & 6.8 & 7.1 & 7.0 & 7.0 & 7.1 & 7.3 & 7.2 & 7.4 & 7.7 & 7.5 \\
\hline $\mathrm{N}(\% \mathrm{TS})$ & 2.5 & 2.6 & 3.4 & 2.6 & 2.8 & 3.1 & 3.1 & 3.3 & 3.8 & 3.5 & 2.9 & 5.3 \\
\hline $\mathrm{C} / \mathrm{N}$ & 17.5 & 17.7 & 13.4 & 17.8 & 16.8 & 15.4 & 15.5 & 14.7 & 12.7 & 14.0 & 18.1 & 9.7 \\
\hline $\begin{array}{l}\text { Carbohydrate: } \\
\text { protein: lipid }\end{array}$ & 12.2:3.4:1 & 2.9:1.1:1 & 3.3:1.6:1 & 2.1:0.7:1 & 2.2:0.9:1 & 1.9:0.9:1 & 1.7:0.9:1 & 1.2:0.8:1 & 1.4:0.9:1 & 1.1:0.7:1 & 0.8:0.5:1 & 0.4:1.1:1 \\
\hline $\mathrm{BMP}\left(\mathrm{mLCH}_{4} / \mathrm{g}\right.$ VS $)$ & 435.1 & 528.9 & 514.6 & 575.5 & 558.9 & 573.5 & 585.9 & 621.2 & 604.8 & 636.0 & 686.9 & 684.1 \\
\hline
\end{tabular}


3 Table 2. Compositions of the 12 types of FW and methane yield.

\begin{tabular}{|c|c|c|c|}
\hline Item & Value range & Mean value and $\mathrm{SD}^{*}$ & Variation range \\
\hline $\mathrm{TS}(\%)$ & $16.7-24.7$ & $19.8 \pm 2.0$ & 8.0 \\
\hline VS (\%) & $16.4-23.5$ & $19.0 \pm 1.8$ & 7.1 \\
\hline Carbohydrate (\%) & $3.1-12.0$ & $8.9 \pm 2.3$ & 9.0 \\
\hline Protein $(\%)$ & $3.4-7.9$ & $4.8 \pm 1.2$ & 4.5 \\
\hline Lipid (\%) & $1.0-10.2$ & $5.4 \pm 2.3$ & 9.2 \\
\hline $\mathrm{C}(\% \mathrm{TS})$ & $43.0-51.5$ & $47.6 \pm 2.5$ & 8.5 \\
\hline $\mathrm{H}(\% \mathrm{TS})$ & $6.5-7.7$ & $7.1 \pm 0.3$ & 1.20 \\
\hline $\mathrm{N}(\% \mathrm{TS})$ & $2.5-5.3$ & $3.2 \pm 0.8$ & 2.8 \\
\hline $\mathrm{C} / \mathrm{N}$ & $9.7-18.1$ & $15.3 \pm 2.5$ & 8.4 \\
\hline $\mathrm{BMP}(\mathrm{mL} / \mathrm{gVS})$ & $435-687$ & $584 \pm 71$ & 252 \\
\hline
\end{tabular}

4 *SD: Standard deviation. 
6 Table 3. ANOVA analysis between different parameters and organics components.

\begin{tabular}{|c|c|c|c|}
\hline Items & Carbohydrate & Protein & Lipid \\
\hline BMP & $0.0418 *$ & 0.0553 & $2.88 \mathrm{e}-06 * * *$ \\
\hline TAN & $0.000499 * * *$ & $0.000749 * * *$ & 0.0553 \\
\hline $\mathrm{pH}$ & $0.0033 * *$ & $0.00347 * *$ & $0.0013 * *$ \\
\hline FA & $0.00026 * * *$ & $0.000261 * * *$ & $0.00649 * *$ \\
\hline Protein reduction & $1.56 \mathrm{e}-07 * * *$ & $7.17 \mathrm{e}-07 * * *$ & $0.0316 *$ \\
\hline Lipid reduction & 0.218 & 0.275 & $0.000143 * * *$ \\
\hline TS reduction & 0.501 & 0.511 & 0.475 \\
\hline VS reduction & 0.239 & 0.251 & 0.583 \\
\hline $\mathrm{t}_{90} \mathrm{a}^{\mathrm{a}}$ & $0.0368 *$ & 0.0555 & $0.00221 * *$ \\
\hline $\mathrm{PV}_{1}{ }^{\mathrm{b}}$ & $0.0275 *$ & 0.0505 & $0.0325 *$ \\
\hline$k_{h}$ & 0.565 & 0.717 & 0.873 \\
\hline $\mathrm{C} / \mathrm{N}$ & $0.00074 * * *$ & $0.0014 * *$ & 0.657 \\
\hline $\mathrm{PV}_{2}{ }^{\mathrm{c}}$ & $0.0242 *$ & 0.051 & 0.0602 \\
\hline
\end{tabular}

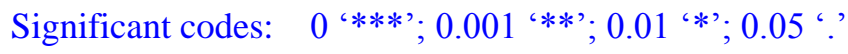

7 a t90: time taken for $90 \%$ of methane production; ${ }^{\mathrm{b}} \mathrm{PV}_{1}$ : the values of the first peaks; ; $\mathrm{PV}_{2}$ : the values of the 8 second peaks.

9 
10 Table 4. Characteristics of the methane production peaks for the 12 samples with different compositions.

\begin{tabular}{|c|c|c|c|c|c|c|c|c|c|c|c|c|}
\hline Parameters & $12.2: 3.4: 1$ & 2.9:1.1:1 & $3.3: 1.6: 1$ & 2.1:0.7:1 & 2.2:0.9:1 & 1.9:0.9:1 & 1.7:0.9:1 & 1.2:0.8:1 & 1.4:0.9:1 & $1.1: 0.7: 1$ & $0.8: 0.5: 1$ & $0.4: 1.1: 1$ \\
\hline \multicolumn{13}{|c|}{1 The first stage (Duration of the first peak) } \\
\hline 1.1 Starting time $(\mathrm{h})$ & 0 & 0 & 0 & 0 & 0 & 0 & 0 & 0 & 0 & 0 & 0 & 0 \\
\hline 1.2 Ending time $(\mathrm{h})$ & 21 & 22 & 13 & 18 & 18 & 18 & 18 & 12 & 12 & 11 & 13 & 12 \\
\hline 1.3 Duration $(\mathrm{h})$ & 21 & 22 & 13 & 18 & 18 & 18 & 18 & 12 & 12 & 11 & 13 & 12 \\
\hline 1.4 PV ${ }_{1}^{\text {a }}(\mathrm{mL} /(\mathrm{g} \mathrm{VS} \mathrm{h}))$ & 63.7 & 26.9 & 14.7 & 25.2 & 26.6 & 26.9 & 43.2 & 18.4 & 15.2 & 13.9 & 17.2 & 12.7 \\
\hline $1.5 \mathrm{OT}^{\mathrm{b}}(\mathrm{h})$ & 11 & 10 & 6 & 10 & 10 & 9 & 9 & 7 & 7 & 7 & 8 & 5 \\
\hline 1.6 Methane (mL/gVS) & 379 & 148 & 116 & 145 & 148 & 150 & 197 & 111 & 108 & 93 & 107 & 92 \\
\hline 1.7 Percentage ${ }^{c}(\%)$ & 98.5 & 29.0 & 25.3 & 27.0 & 27.7 & 28.3 & 35.9 & 19.6 & 20.0 & 17.1 & 17.0 & 16.1 \\
\hline
\end{tabular}

2 The second stage (Begin from the ending time of the first peak, till t90 ${ }^{d}$ )

\begin{tabular}{|c|c|c|c|c|c|c|c|c|c|c|c|c|}
\hline 2.1 Starting time $(\mathrm{h})$ & - & 23 & 14 & 19 & 19 & 19 & 19 & 13 & 13 & 12 & 14 & 13 \\
\hline 2.2 Ending time (h) & - & 343 & 231 & 245 & 212 & 202 & 196 & 369 & 363 & 383 & 409 & 348 \\
\hline 2.3 Duration (h) & - & 320 & 217 & 226 & 193 & 183 & 177 & 356 & 350 & 371 & 395 & 335 \\
\hline $2.4 \mathrm{PV}_{2}{ }^{\mathrm{a}}(\mathrm{L} /(\operatorname{kgVS~h}))$ & - & 4.4 & 7.5 & 4.4 & 3.7 & 3.4 & 4.0 & 7.6 & 8.7 & 7.1 & 6.3 & 6.8 \\
\hline $2.5 \mathrm{OT}^{\mathrm{b}}(\mathrm{h})$ & - & 145 & 18 & 66 & 66 & 27 & 24 & 18 & 16 & 16 & 16 & 16 \\
\hline 2.6 Methane (mL/gVS) & - & 311 & 297 & 337 & 333 & 327 & 300 & 397 & 381 & 397 & 457 & 424 \\
\hline 2.7 Percentage ${ }^{\mathrm{c}}(\%)$ & & 61.0 & 64.5 & 62.8 & 62.2 & 61.6 & 54.7 & 70.3 & 70.3 & 72.9 & 72.9 & 73.9 \\
\hline
\end{tabular}

\begin{tabular}{|c|c|c|c|c|c|c|c|c|c|c|c|c|}
\hline 2.1 Percentage $-(\%)$ & & & 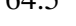 & & 02.2 & & .1 & On & . & & Y & \\
\hline \multicolumn{13}{|l|}{3 Total AD process } \\
\hline 3.1 Methane (mL/gVS) & 385 & 509 & 460 & 536 & 536 & 530 & 548 & 565 & 541 & 545 & 627 & 574 \\
\hline 3.2 Percentage $\mathrm{e}(\%)$ & 88.4 & 96.2 & 89.5 & 93.2 & 95.9 & 92.5 & 93.5 & 90.9 & 89.5 & 85.7 & 91.3 & 84.0 \\
\hline
\end{tabular}

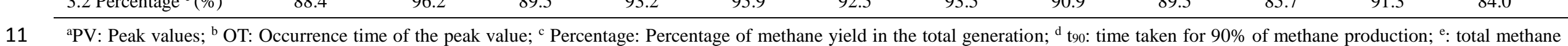

12 yield/ BMP 
13 Table 5. Coefficients of the regression models and a comparison of the predicted and experimental results.

\begin{tabular}{|c|c|c|c|c|c|c|c|c|c|c|c|}
\hline \multirow{2}{*}{ Item } & \multicolumn{6}{|c|}{$M=M_{0}+a X+b Y+c X^{2}+d Y^{2}+e X Y$} & \multirow{2}{*}{$R^{2}$} & \multicolumn{2}{|l|}{ Sample 1} & \multicolumn{2}{|l|}{ Sample 2} \\
\hline & $M_{0}$ & $a$ & $b$ & $c$ & $d$ & $e$ & & Predicted & Measured & Predicted & Measured \\
\hline $\mathrm{CH}_{4}(\mathrm{~mL} / \mathrm{gVS})$ & 348 & 12 & 4736 & 143 & -18719 & -3505 & 0.958 & 519 & 646 & 575 & 510 \\
\hline$k_{\mathrm{h}}\left(\mathrm{d}^{-1}\right)$ & -2 & 72 & 35 & 155 & 197 & -1345 & 0.759 & 0.3 & 0.1 & 0.4 & 0.3 \\
\hline $\mathrm{t}_{90}(\mathrm{~h})^{\mathrm{a}}$ & -169 & 6426 & 6298 & -32215 & -18790 & -21149 & 0.727 & 233 & 305 & 350 & 284 \\
\hline $\mathrm{PV}_{1}(\mathrm{~mL} /(\mathrm{g} \mathrm{VS} \mathrm{h}))^{\mathrm{b}}$ & 86 & -884 & -968 & 3025 & 4149 & 4504 & 0.572 & 30 & 15 & 17 & 27 \\
\hline $\mathrm{PV}_{2}(\mathrm{~mL} /(\mathrm{g} \mathrm{VS} \mathrm{h}))^{\mathrm{c}}$ & -30 & 847 & 456 & 1593 & 1994 & -14786 & 0.791 & 3.1 & 2.9 & 6.1 & 3.0 \\
\hline TAN (mg/L) & 1554 & 11403 & -10907 & -59695 & 38530 & 172388 & 0.897 & 1751 & 1121 & 2054 & 1743 \\
\hline FAN (mg/L) & 64 & 1212 & 57 & 35437 & 22614 & -41726 & 0.952 & 134 & 71 & 187 & 133 \\
\hline $\mathrm{pH}$ & 7.6 & -0.2 & 6.5 & 180.3 & 69.9 & -277.8 & 0.941 & 7.82 & 7.77 & 7.87 & 7.80 \\
\hline Protein reduction $(\%)$ & 0.4 & 1.5 & 1.5 & 38.5 & 9.8 & -53.4 & 0.984 & 53.9 & 60.9 & 57.7 & 53.8 \\
\hline Lipid reduction (\%) & 0.7 & -5.6 & 6.0 & -32.3 & -60.9 & 105.9 & 0.988 & 69.5 & 52.6 & 84.3 & 79.7 \\
\hline
\end{tabular}

$14{ }^{\mathrm{a}} \mathrm{t}_{90}$ : time taken for $90 \%$ of methane production; ${ }^{\mathrm{b}} \mathrm{PV}_{1}$ : Peak value in the first stage; ${ }^{\mathrm{c}} \mathrm{PV}_{2}$ : Peak value in the second stage. 


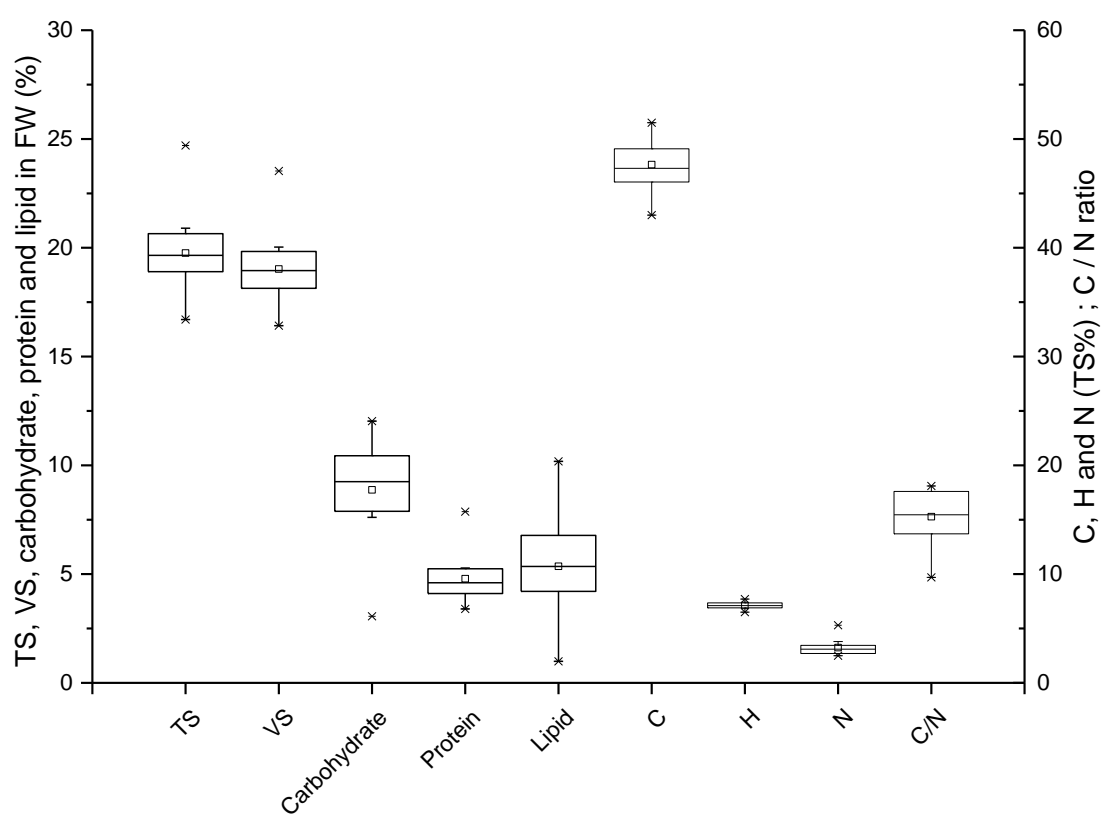

16 Fig.1. Characteristics of the 12 types of FW used in this study (Range: $25 \%$ and 17 $75 \%)$ 


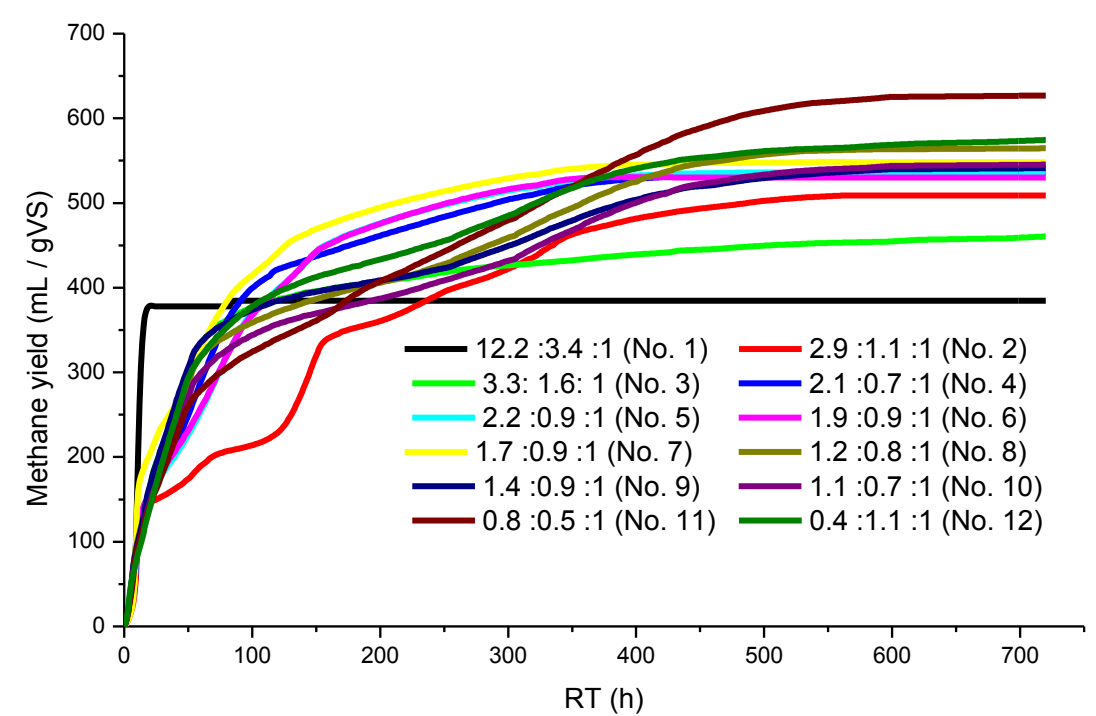

18

(a)
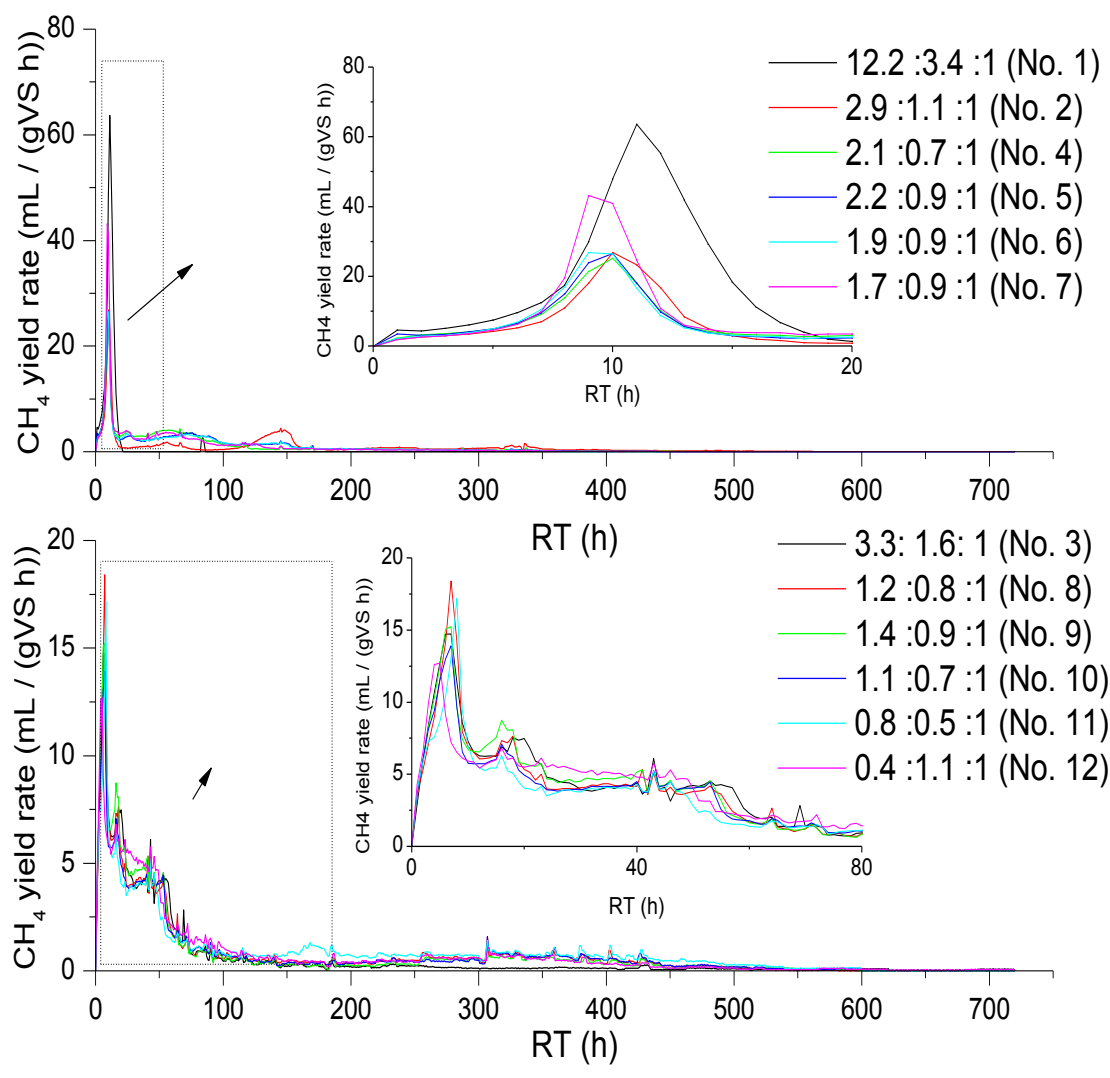

20

(b)

22 Fig. 2. Development of methane production patterns (a) and specific methane

23 production rates (b) of FW with different compositions. 


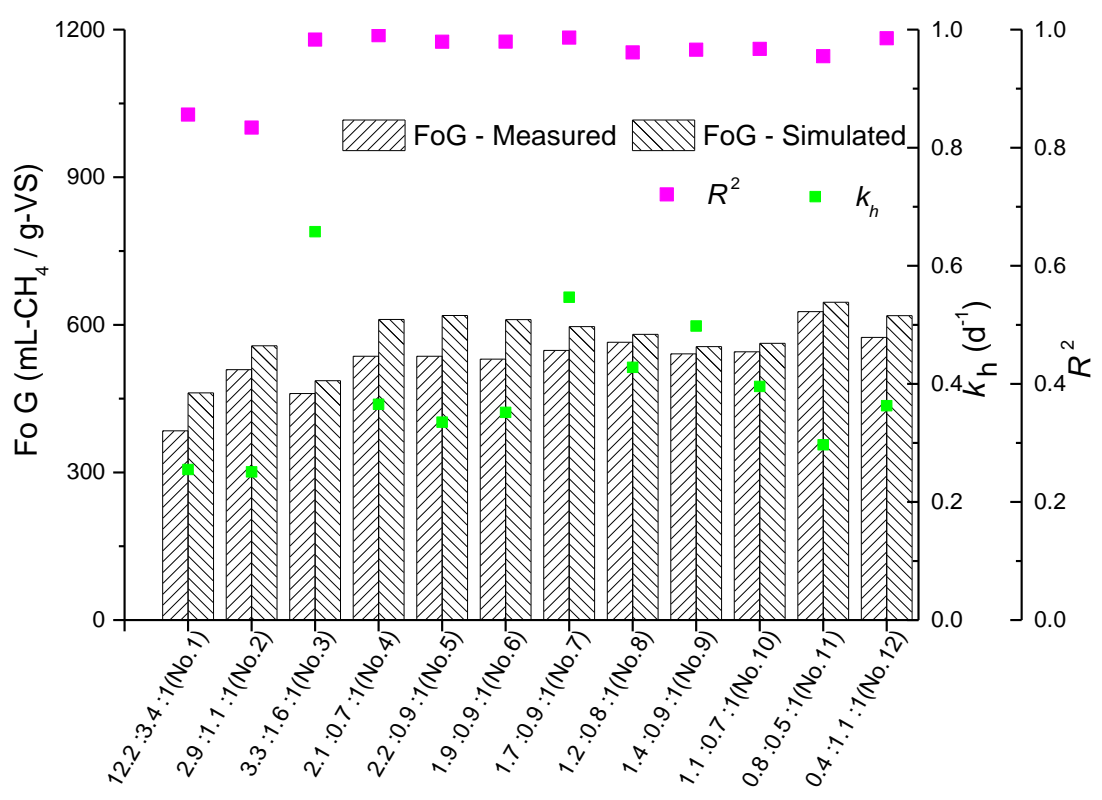

Fig. 3. Results of kinetic study using the approach of Koch and Drewe. 


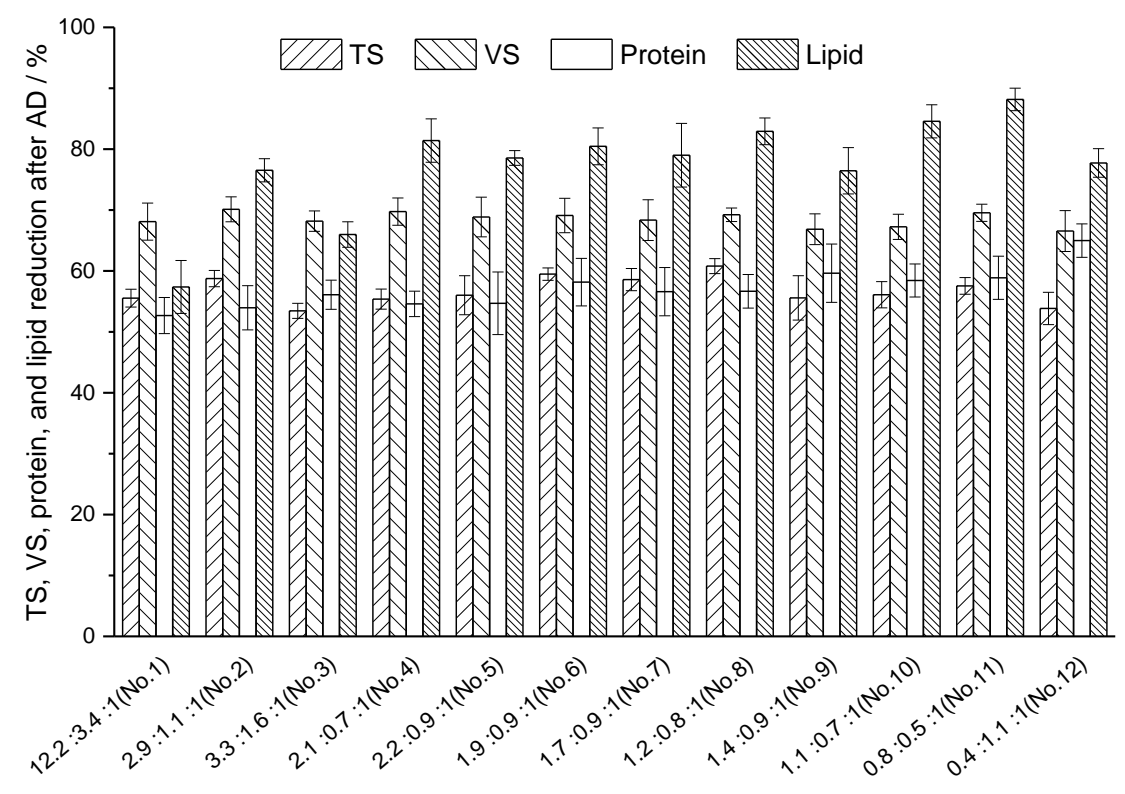

Fig. 4. Reduction of the TS, VS, proteins, and lipids after 30 days of AD. 


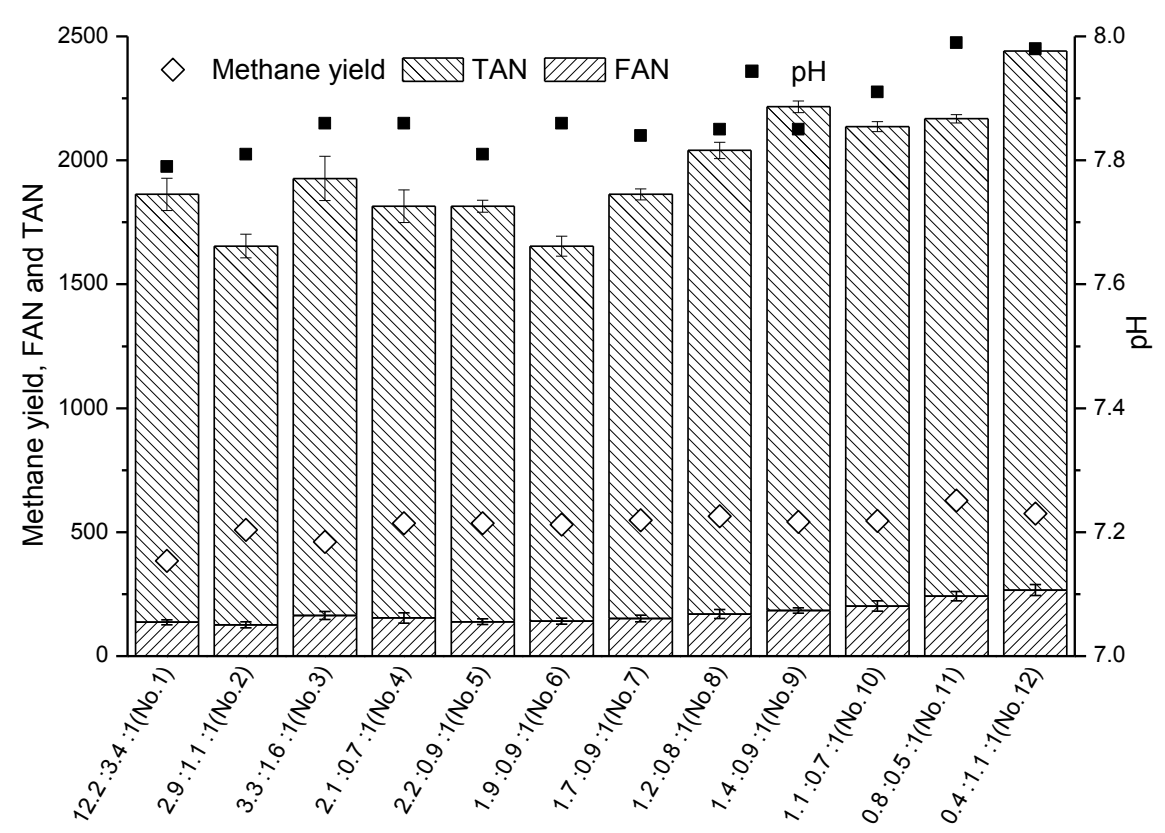

29 Fig. 5. The relationship between TAN, FAN, pH and methane yield after 30 days of 30 AD. 